\title{
Supporting the Model of Ductile Iron Dendritic Solidification**
}

By Henrique M. C. M. Santos, * A. M. P. Pinto, M. C. P. L. Jacinto, and C. P. M. Sá

The literature about graphite formation in ductile iron proposes the experimentally supported theory that this phase forms in the melt. ${ }^{[1-4]}$

This is naturally accepted as a consequence of the eutectic reaction of the iron-carbon equilibrium diagram. This reaction

[*] Dr. H. M. C. M Santos

Metallurgy and Materials Department

Engineering School

Porto University

Porto (Portugal)

Email: hsantos@fe.up.pt

Dr. A. M. P. Pinto

Mechanical Engineering Department

Minho University

Minho (Portugal)

Dr. M. C. P. L. Jacinto

Mechanical Engineering Department

Porto Polytechnic Institute and INEGI

Porto (Portugal)

Dr. C. P. M. Sá

Materials Centre

Porto University

Porto (Portugal)

[**] This work is part of the project PRAXIS XXI 3/3.1/CEG/2666/95 financed by the Portuguese PRAXIS program. Thanks are due to FERESPE for having provided some of the material used in the experiments. The Porto Mining and Geology Institute is thanked for having provided facilities for some of the microanalysis. 
requires that during cooling, at $1150-1100^{\circ} \mathrm{C}$, the liquid with a eutectic composition decomposes into two solid phases, pure graphite and austenite with a carbon content close to $2 \%$ in weight. If the ductile irons have a generally eutectic composition, the presence of neither pro-eutectic graphite nor austenite seems necessary for eutectic graphite formation.

According to the proposed solidification path, the graphite nodules become encapsulated by an austenite case, resulting in a loss of contact between liquid and graphite. Carbon will then have to diffuse from the liquid through the austenite to the graphite to allow further growth of both solid phases.

This growth mechanism is responsible for a specific segregation pattern at the scale of the eutectic cell. During solidification, a carbon gradient has to exist against the graphite phase; this composition gradient constitutes the driving force for carbon diffusion. This means that the carbon content must increase with the distance to the nodule, achieving its equilibrium content in the homogeneous liquid far from the graphite nodule. In fact, the liquid surrounding the austenite shell has to be carbon enriched, otherwise diffusion will not occur. So a carbon-rich liquid will be the last melt to solidify and will be located at the eutectic cell boundaries.

Simultaneously with carbon segregation, alloying elements also play a role in chemical partitioning: some will remain in the liquid phase and will concentrate in the last regions to solidify and others will migrate to the solid matrix surrounding the graphite nodule, being associated with the early-solidified regions. Carbide-forming elements like $\mathrm{Mn}, \mathrm{Cr}$, and $\mathrm{Mo}$ will segregate (positively) to the eutectic cell boundaries. Non-carbide forming elements like $\mathrm{Si}, \mathrm{Cu}$, and $\mathrm{Ni}$ will segregate (negatively) to the so-called graphite/matrix interface. An effective partition, or segregation, coefficient $k$ is defined for each element as the ratio between the content of the element in the graphite noduie interface and the content of the same element in the eutectic cell boundary; $k$ is greater than unity for elements with negative microsegregation and less than unity for elements with positive microsegregation.

All these issues were established long ago in the literature and are supported by numerous analytical techniques. ${ }^{[4,5-8]}$

If this model reflects reality, the described mode of microsegregation would be detected in the matrix joining two adjacent graphite nodules, where it intercepts a cell boundary.

We have been dealing with this microsegregation question for a long time, being engaged for more than ten years in austempered ductile iron (ADI) studies, in which microsegregation phenomena are important due to their effect on the kinetics of austenite decomposition in the bainitic domain Some results obtained did not appear to be coherent with the model presented above.

A recent publication proposing a new approach to ductile iron solidification ${ }^{[9]}$ induced us to recall some data from previous work and to conduct some new experiments to analyze this particular problem in more detail. These facts, and their interpretation in the light of the new ideas about ductile iron solidification, are presented in this communication.
In this work several ductile iron alloys have been studied. They differed in composition and in the processing routes. Two of the alloys (A1 and A2) were supplied by an iron foundry and the other two ( $\mathrm{A} 3$ and $\mathrm{A} 4$ ) were produced under laboratory conditions.

The alloys A1 and A2 were electrically melted in a furnace of $150 \mathrm{~kg}$ capacity with a base composition suitable for ferritic ductile iron production and treated by the "flow-through" process; $\mathrm{Cu}$ and $\mathrm{Mn}$ were added to the melt after nodularizing it, in the form of electrolytic $\mathrm{Cu}$ and $\mathrm{Fe}-\mathrm{Mn}$ (75 wt.-\% Mn). Alloys $\mathrm{A} 1$ and $\mathrm{A} 2$ were cast in resin-bonded sand in the form of cylinders. A1 cylinders were $25 \mathrm{~mm}$ in diameter and $200 \mathrm{~mm}$ long; A2 cylinders were $80 \mathrm{~mm}$ in diameter and $300 \mathrm{~mm}$ long.

The melting of alloys A3 and A4 was conducted in a coreless induction furnace of $100 \mathrm{~kg}$ capacity. The melt was treated by a sandwich process. Alloys A3 and A4 were cast in resin-bonded sand and gravity die-cast. In gravity die-casting, two inoculation stages were performed. Y-blocks $25 \mathrm{~mm}$ thick were cast in open molds made of furanic resin sand. For gravity die-casting, a permanent die with an area of $365 \times$ $500 \mathrm{~mm}^{2}$ and maximum thickness of $30 \mathrm{~mm}$ was used; cylinders of $200 \mathrm{~mm}$ in height and $30 \mathrm{~mm}$ diameter were poured.

Table 1 displays the average composition of the alloys, obtained by atomic emission spectrometer analysis on chill cast discs of several samples.

The graphite nodularity of all alloys is better than $85 \%$. The nodule density of the sand- and die-cast alloys is about 300 nodules $/ \mathrm{mm}^{2}$ and 2000 nodules $/ \mathrm{mm}^{2}$ respectively. Different fractions of pearlite and ferrite were identified as the constituents of the metallic matrix in the as-cast state.

The microsegregation of $\mathrm{Si}, \mathrm{Cu}$, and $\mathrm{Mn}$ was evaluated using two different approaches. A scanning electron microscope equipped with an energy dispersive spectrometer was used to characterize the distribution in alloys $\mathrm{A} 1$ and $\mathrm{A} 2$; a microprobe equipped with a wavelength dispersive spectrometer was used to characterize the distribution in alloys A3 and A4.

The microsegregation studies were performed over transverse sections.

The regions to be microanalyzed were selected using an imaginary straight line defined between two adjacent nodules. This line was divided in several equal segments and the microanalysis was performed at the end of each segment.

As the internodular distance was not constant, it was normalized. At least ten internodular distances, from different fields of view, were studied per sample, corresponding to some hundreds of analyses.

Table 1. Altoy composition (wt. $-\%$ ).

\begin{tabular}{lllll} 
Alloy & $\mathrm{C}$ & $\mathrm{Si}$ & $\mathrm{Mn}$ & $\mathrm{Cu}$ \\
\hline $\mathrm{A} 1$ & 3.82 & 3.30 & 0.56 & 0.96 \\
$\mathrm{~A} 2$ & 3.37 & 2.50 & 0.56 & 1.09 \\
$\mathrm{~A} 3$ & 3.45 & 3.06 & 0.26 & 0.30 \\
$\mathrm{~A} 4$ & 3.43 & 3.04 & 0.55 & 0.92
\end{tabular}


On the alloys $\mathrm{A} 1$ and $\mathrm{A} 2, \mathrm{Si}, \mathrm{Mn}$, and $\mathrm{Cu}$ contents were measured using SEM/EDS (Jeol35C/Noran-Voyager), acquiring data at each point over the $2 \times 2 \mu \mathrm{m}^{2}$ probe. The microanalysis was conducted at $15 \mathrm{keV}$ excitation voltage and the acquisition time was $2 \mathrm{~min}$.

Camebax equipment was used for the microanalysis of alloys $\mathrm{A} 3$ and $\mathrm{A} 4$ using an accelerating voltage of $15 \mathrm{keV}$ and a beam current of $21 \mathrm{nA}$. Reference standards of pure elements were used for the quantitative analysis.

For both techniques the weight percentage of each element was calculated using a program accounting for Z,AF corrections.

Once silicon and copper segregate negatively during the solidification of ductile iron and manganese segregates positively, one may assume that the higher concentration of $\mathrm{Si}$ and $\mathrm{Cu}$ are associated with the lower Mn content. Therefore, our microanalysis results will be presented in a way that shows this relationship: the ratios $\mathrm{Si} / \mathrm{Mn}$ and $\mathrm{Cu} / \mathrm{Mn}$ are plotted versus $\mathrm{Mn}$ content. Figure 1 shows these relationships for alloy A1.

The results show that there is a trend for high concentrations of $\mathrm{Si}$ and $\mathrm{Cu}$ to be associated with low concentrations of $\mathrm{Mn}$ and vice-versa. This behavior is common to all four alloys, as shown in Figure 2, which presents all the collected data.

According to the classical accepted solidification model described above the solidification of the metallic matrix begins close to the graphite nodules, enveloping them and avoiding their contact with the liquid phase; this implies that the highest levels of $\mathrm{Si}$ and $\mathrm{Cu}$ are associated with the regions that first solidify. The graphite matrix interfaces are then $\mathrm{Si}$ and $\mathrm{Cu}$ enriched and $\mathrm{Mn}$ depleted, whilst the lowest contents of $\mathrm{Si}$ and $\mathrm{Cu}$ are associated with the last regions to solidify (i.e., the eutectic cell boundaries), which are supposed to be $\mathrm{Mn}$ enriched.

Figure 3 displays the $\mathrm{Si} / \mathrm{Mn}$ and $\mathrm{Cu} / \mathrm{Mn}$ evolution along several internodular lines for alloy A2. In agreement with the microsegregation model, the higher $\mathrm{Si} / \mathrm{Mn}$ and $\mathrm{Cu} / \mathrm{Mn}$ ratios must be associated with regions close to the graphite matrix interface and the lower figures of those ratios must be associated with eutectic cell boundaries.
This means that the profile of the $\mathrm{Si} / \mathrm{Mn}$ and $\mathrm{Cu} / \mathrm{Mn}$ ratios versus the distance to the graphite matrix interface should be a U-shaped curve. Our results clearly contradict this statement: in a great number of cases the $\mathrm{Si} / \mathrm{Mn}$ and $\mathrm{Cu} / \mathrm{Mn}$ ratios versus the graphite matrix interface distance do not give a U-shaped curve. In some cases, there is $\mathrm{Si}$ and $\mathrm{Cu}$ enrichment at the interface while in others there is a depletion of these elements and a Mn enrichment. This behavior is similar for all alloys studied in this work.

In the face of this peculiar result, several more nodule/ matrix interfaces in alloy A2 were submitted to microanalysis; in each interface four measurements were performed at $90^{\circ}$ to each other, with the aim of confirming the occurrence
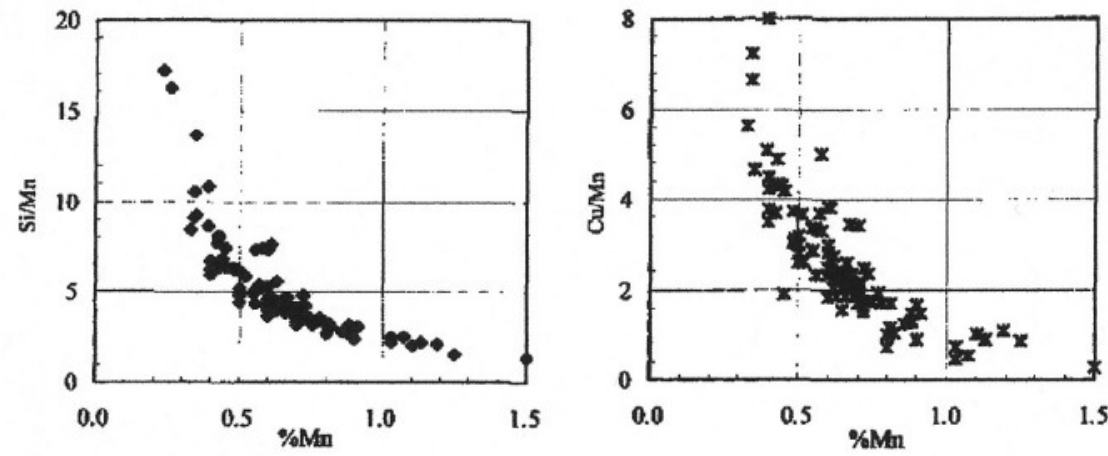

Fig. 7. Relation of Si/Mn and Cu/Mn vs. Mn in the case of alloy A1
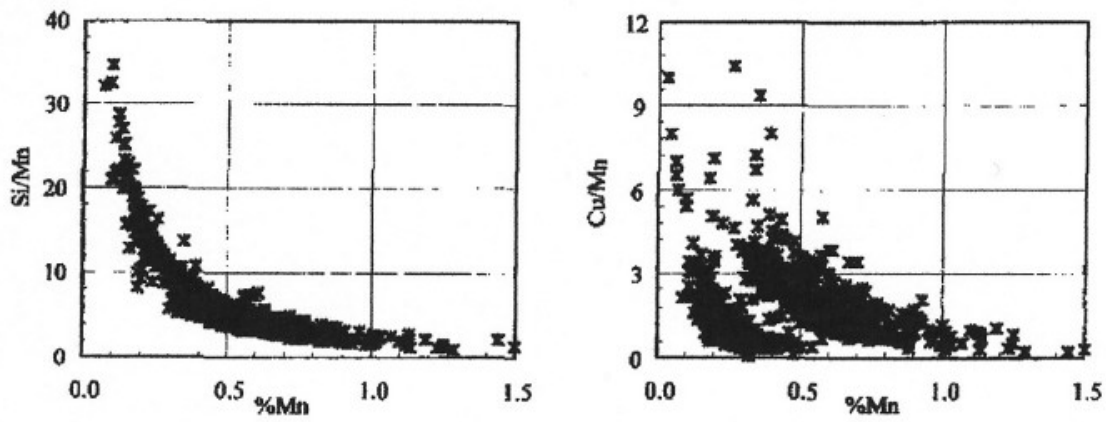

Fig. 2. Reintion of Si/Mn and Cu/Mn os. Mn for all four alloys.
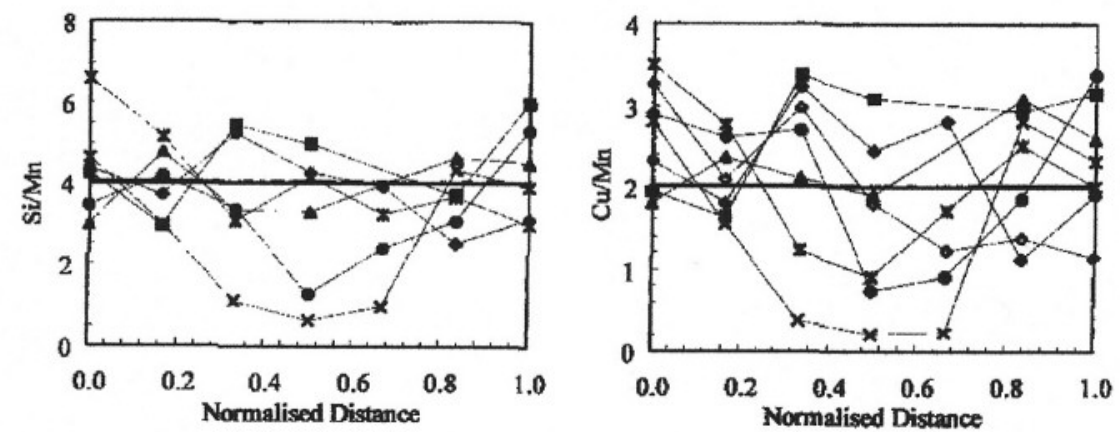

Fig. 3. Enointion of Si/Mn and $\mathrm{Cu} / \mathrm{Mn}$ us. normatized intennodular distance in several internodular regions in the case of alloy A2 (the horizontal lines indicate the Si/Mn and $\mathrm{Cu} / \mathrm{Mn}$ nominal ratio of the alloy). 
of $\mathrm{Si} / \mathrm{Mn}$ and $\mathrm{Cu} / \mathrm{Mn}$ maximum figures. Figure 4 plots the $\mathrm{Si} / \mathrm{Mn}$ and $\mathrm{Cu} / \mathrm{Mn}$ ratios in the neighborhood of the nodule/ matrix interface.

The results show that the graphite matrix interface is not systematically $\mathrm{Si}$ and $\mathrm{Cu}$ enriched and $\mathrm{Mn}$ depleted: in fact, more then $50 \%$ of the analyzed points present a $\mathrm{Si} / \mathrm{Mn}$ ratio lower than the nominal ratio for the alloy (which is 4.45 in the case of alloy A2). The $\mathrm{Cu} / \mathrm{Mn}$ nominal ratio for the alloy is 1.96 and more than $30 \%$ of the analyzed points give lower figures. It was also verified in each graphite matrix interface that there was a strong dispersion of $\mathrm{Si} / \mathrm{Mn}$ and $\mathrm{Cu} / \mathrm{Mn}$ ratio, achieving variations as high as 3:1.

Table 2 supports this verification, showing the maximum and minimum figures for the $\mathrm{Si} / \mathrm{Mn}$ and $\mathrm{Cu} / \mathrm{Mn}$ ratios in several nodule/matrix interfaces.
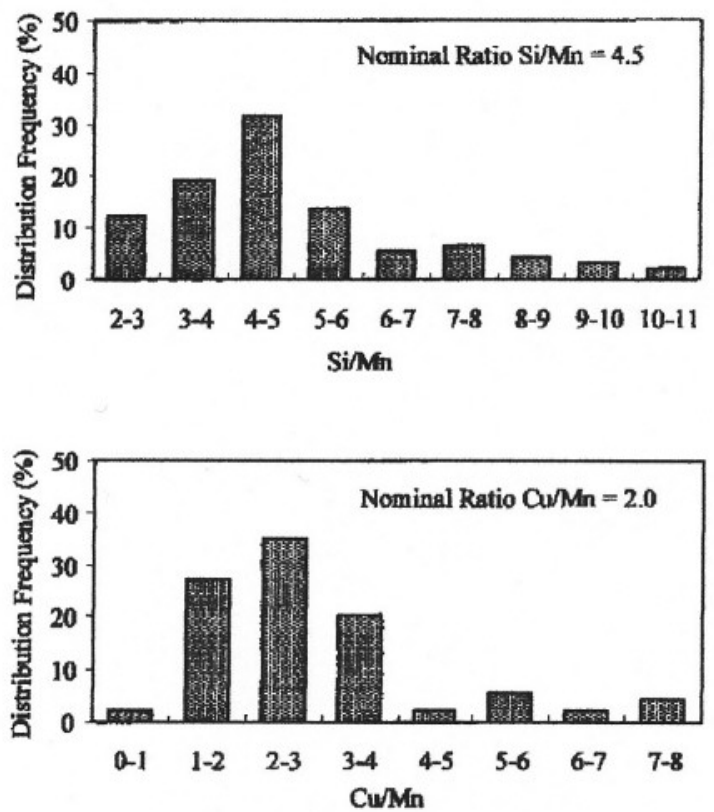

Fig. 4. Distribution frequency of Si/Mn and Cu/Mn ratio in the case of alloy A2.

Table 2. Si/Mn and Cu/Mn natios (nominal ratios, minimum, and maximum values) on ten different nodule/matrix interfaces, in the case of the alloy $\mathrm{A} 2$.

\begin{tabular}{|c|c|c|c|c|c|c|c|c|c|c|}
\hline & \multicolumn{10}{|c|}{ Nodule/matrix interface } \\
\hline & 1 & 2 & $\frac{1}{3}$ & 4 & 5 & 6 & 7 & 8 & 9 & 10 \\
\hline $\begin{array}{l}\mathrm{Si} / \mathrm{Mn} \\
\text { (nominal) }\end{array}$ & \multicolumn{10}{|c|}{4.5} \\
\hline $\begin{array}{l}\text { Si/Mn } \\
(\min )\end{array}$ & 2.4 & 4.5 & 4.6 & 3.3 & 3.6 & 4.4 & 5.0 & 4.5 & 4.0 & 4.3 \\
\hline $\begin{array}{l}\mathrm{Si} / \mathrm{Min} \\
\text { (t) }\end{array}$ & 7.0 & 8.6 & 9.4 & 7.0 & 8.3 & 8.6 & 9.1 & 10.6 & 8.3 & 7.4 \\
\hline $\begin{array}{l}\mathrm{Cu} / \mathrm{Mn} \\
\text { (nominal) }\end{array}$ & \multicolumn{10}{|c|}{2.0} \\
\hline $\begin{array}{l}\text { Cw/M/n } \\
\text { (min) }\end{array}$ & 1.6 & 2.1 & 3.8 & 1.6 & 1.9 & 1.9 & 2.5 & 3.1 & 21 & 2.3 \\
\hline $\begin{array}{l}\mathrm{Cu} / \mathrm{Mn} \\
(\max )\end{array}$ & 5.5 & 5.3 & 7.1 & 5.6 & 5.9 & 7.7 & 7.4 & 7.1 & 6.8 & 39 \\
\hline
\end{tabular}

The results reported above are not consistent with the melt theory that suggests that graphite is formed directly from the melt and soon surrounded by an austenite shell, requiring carbon diffusion for further growth. This growth model imposes on the austenite shell a high content of graphitizing elements $(\mathrm{Si}, \mathrm{Cu})$ and a low content of carbide forming elements (C, Mn).

Although we have confirmed that $\mathrm{Si}$ and $\mathrm{Cu}$ segregate inversely with $\mathrm{Mn}$, a clear contradiction was evident when the $\mathrm{Si} / \mathrm{Mn}$ and $\mathrm{Cu} / \mathrm{Mn}$ ratios were evaluated along the internodular path. The high $\mathrm{Si} / \mathrm{Mn}$ and $\mathrm{Cu} / \mathrm{Mn}$ figures were not generally associated with the graphite matrix interfaces, but were present elsewhere. In fact, one should find that somewhere along this path the $\mathrm{Si} / \mathrm{Mn}$ and $\mathrm{Cu} / \mathrm{Mn}$ ratios have minima; quite different profiles were obtained as shown in Figure 3. It has been possible to verify that the minima in $\mathrm{Si} / \mathrm{Mn}$ and $\mathrm{Cu} / \mathrm{Mn}$ ratios may occur even in the nodule/matrix interface, suggesting that the metallic matrix enveloping the nodules results from the last solidified liquid, which is $\mathrm{C}$ and $\mathrm{Mn}$ enriched and $\mathrm{Si}$ and $\mathrm{Cu}$ depleted.

Several microanalyses around each graphite/matrix interface, performed for one of the alloys, showed that the distribution of the chemical elements did not follow the pattern forecasted by the melt theory for the graphite formation. Intense chemical dispersion of $\mathrm{Si} / \mathrm{Mn}$ and $\mathrm{Cu} / \mathrm{Mn}$ was observed and both positive and negative microsegregation was evaluated, as may be demonstrated by the data presented in Table 2. This behavior requires the solid surrounding the nodule to be formed from liquid fractions with different compositions.

In view of these facts we suppose that the ductile iron solidification has to occur by another model, different from the melt theory. In a recent paper by Van de Velde, ${ }^{[9]}$ a dendritic model for this process is proposed; the author claims that enough evidence is available to justify the rejection of the traditional idea of graphite formation directly from the melt. In the past, several researchers advanced theories about solidification of ductile iron based on austenite dendrite formation, namely the cementite theory and the austenite theory (proposed by Dunphy and Pellini and by De Sy ${ }^{[9]}$ ) but they were ignored due the popularity of the melt theory. More recently Stefanescu ${ }^{[2]}$ claimed that austenite dendrites play an important role in the solidification of the ductile irons, proposing that they would form simultaneously with graphite and embrace the nodules, producing what the author calls "the eutectic grain".

According to Van de Velde, ${ }^{[9]}$ ductile iron solidification is a process in which the eutectic liquid transforms into austenite dendrites and enriches in carbon, in fact a mechanism identical to the one universally accepted for the bainitic reaction. With the progress of the reaction, the liquid will finally segregate carbon to the interdendritic interstices, amongst the dendrite branches. Due to the low specific mass of carbon, a considerable expansion is associated with its precipitation, the spherical morphology being accepted as natural. This hypothesis is quite compatible with the results presented in this work. 
Our results require that, during solidification, a growing nodule must be in contact simultaneously with early and late regions to solidify. This is a reasonable way to explain the high dispersion of the $\mathrm{Si} / \mathrm{Mn}$ and $\mathrm{Cu} / \mathrm{Mn}$ ratios in the graphite matrix interfaces and the irregular profiles for $\mathrm{Si} /$ $\mathrm{Mn}$ and $\mathrm{Cu} / \mathrm{Mn}$ ratios along the internodular regions. When a growing nodule has in its neighborhood an early-formed dendrite branch, its interface will be $\mathrm{Si}$ and $\mathrm{Cu}$ enriched. When the nodule touches a residual solidifying melt or a late-formed dendrite branch, its interface will be Mn enriched. If one accepts that graphite nodules nucleate from the interdendritic liquid instead of nucleating from the initial melt, this explanation becomes plausible. In this case, the growth of graphite will occur in contact with austenite formed sooner or later in the solidification process, which means that the austenite will be chemically heterogeneous, making possible high compositional variations of the graphite/matrix interface

Figure 5 shows the as-cast microstructure of the alloy A3 die-cast, resulting from a special etching procedure, from Boutobari et al., ${ }^{[10 \mid}$ used to show the primary solidification structure: the whiter regions indicate high Mn contents. It is obvious that the graphite nodules are in contact with regions with quite different Mn content. Rundman ${ }^{[11]}$ has also reported data showing high Mn content close to the graphite/ matrix interfaces. All these arguments are coherent with Van de Velde ideas and in contradiction with the classical graphite formation theory.

Micro segregation studies over four different ductile irons showed that $\mathrm{Si}$ and $\mathrm{Cu}$ segregate inversely with $\mathrm{Mn}$.

$\mathrm{Si} / \mathrm{Mn}$ and $\mathrm{Cu} / \mathrm{Mn}$ determinations showed considerable variation and the expected decrease with increasing distance to a nodule was not evident.

A great dispersion of the $\mathrm{Si} / \mathrm{Mn}$ and $\mathrm{Cu} / \mathrm{Mn}$ ratios was determined after local microsegregation measures in the metallic matrix interface close to the graphite nodule.

A great number of microanalysis measurements in the metallic matrix did show that the interfaces close to the graphite nodules may present $\mathrm{Si} / \mathrm{Mn}$ and $\mathrm{Cu} / \mathrm{Mn}$ ratios lower than the nominal composition of the alloy.

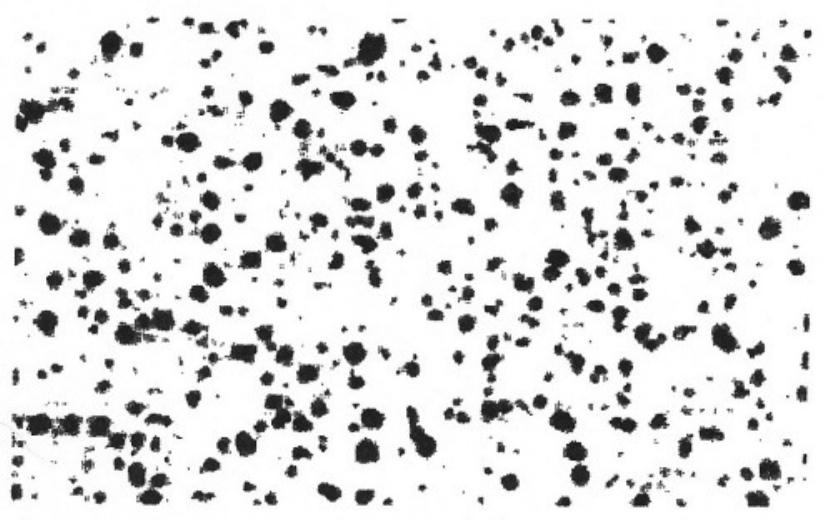

Fig. 5. Optical as-cast microstructure of alloy 13 die cast showing the variations on $\mathrm{Mn}$ content (whiter areas are $\mathrm{Mn}$ enriched regians) ( $\times 706)$ ).
The results obtained in this work are in contradiction with the microsegregation pattern imposed by the mechanism of graphite growing from the melt and become plausible if the mechanism of dendritic ductile iron solidification is assumed.

Received: December 9, 1999

Final version: March 27, 2000

[1] C. R. Loper, R.W. Heine, AFS Trans. 1962, 583.

[2] D. Stefanescu, Proc. 61st World Foundry Congress, Beijing Giesserei Verlag, Düsseldorf, 1995, 8.

[3] S. E. Wetterfall, H. Fredriksson, M. Hillert, J. Iron Steel Inst. 1972, May, 162.

[4] E. Dorazil, High Strength Austempered Ductile Iron, Ellis Horwood Series in Metals and Associated Materials, Hemel Hempstead, UK 1991, p. 13.

[5] J. M. Schissler, J. Saverna, J. Heat Treat. 1985, 4, 167.

[6] N. K. Data, N. N. Engel, AFS Trans. 1976, 431.

[7] J. Janowak, R. Gundlach, AFS Trans. 1983, 377.

[8] R.C. Voight, C.R. Loper, Proc. 1st Int. Conf. ADI, Rosemont, Chicago, Illinois, 2-4 Apr 1984, ASM, Metals Park (OH), 1984, p. 83.

191 C. A. Van de Velde, The Solidification of Ductile Cast Iron - a New Approach, AFS Special Report, American Foundrymen's Society, Des Plaines, IL, 1997.

[10] S. M. A. Boutorabi, J. Campbell, Mater. Charact. 1993, $31,127$.

[11] K. B. Rundman, Proc. Int. ADI Simulation Conf., Helsinki University of Technology, Helsinki Finland, 1997. 